\title{
EFFECT OF DIVIDEND POLICY (DPR), LIQUIDITY (CR) AND PROFITABILITY ON SHARE PRICE AT TRADE, SERVICE AND INVESTMENT SECTORS AT INDONESIA STOCK EXCHANGE IN PERIOD OF 2014-2018
}

\author{
Yeni Ariesa $^{1}$ Yolanda Pebrina Cristy Br. Sitepu ${ }^{2}$ \\ Fakultas Ekonomi, Universitas Prima Indonesia \\ yeni.aries@yahoo.com ${ }^{1}$, yolandapebrina1313@gmail.com²
}

\begin{abstract}
Stock price is one indicator that shows investor interest in owning a company's stock. An investor always expects a stable stock price and has a pattern of movement that tends to rise from time to time, but in fact the stock price tends to fluctuate. Fluctuating stock prices become a risk for investors. Therefore, an investor must understand the issues that must be considered in determining investment decisions. The research variables are Dividend Payout Ratio (DPR), Liquidity (CR), and Profitability (NPM) and Share Prices. The research populations were Trade, Service and Investment Sector Companies listed on the Indonesia Stock Exchange in 2014-2018. The research samples were drawn by using a purposive sampling technique. The research samples were 17 company financial statements that met the criteria as a sample of the company. The datacollection was performed by documentation techniques and the research data were analyzed by using multiple linear analysis. Hypothesis testing shows that the Individual Payout Ratio (DPR) and Liquidity (CR) do not have a significant effect on stock prices. Profitability (NPM) has a significant effect on Stock Prices. The value of Adjusted $R$ Square was 0.275 indicating that variations in the DPR, CR, and NPM can explain variations in the variable Stock Price up to $27.5 \%$ while the remaining $72.7 \%$ can be explained by other factors outside the variables that have not been examined.
\end{abstract}

Keywords: Dividend Payout Ratio (DPR), Current Ratio (CR), Net Profit Margin (NPM), Share Price

\section{PENDAHULUAN}

\subsection{Latar Belakang}

Harga saham di Bursa Efek Indonesia ditentukan oleh kekuatan permintaan dan penawaran. Pada saat permintaan akan saham meningkat maka harga saham tersebut akan cenderung meningkat pula, namun sebaliknya pada saat banyak investor yang menjual sahamnya maka harga akan saham tersebut cenderung akan mengalami penurunan. Pasar modal mempunyai peran yang strategis dalam pembangunan nasional sebagai salah satu sumber pembiayaan bagi dunia usaha dan wahan investasi bagi masyarakat. Melalui pasar modal memungkinkan suatu perusahaan dapat menerbitkan surat berharga (sekuritas), baik surat tanda hutang (obligasi atau bond), maupun surat tanda kepemilikan (saham).

Perusahaan yang dipilih dalam penelitian ini adalah perusahaan sektor trade, service, and investment yang merupakan salah satu sektor yang termasuk dalam Indeks Saham Sektoral BEI. Alasan peneliti memilih sektor trade, service, and investment karena sektor trade, service, and investment diprediksi akan mencetak kenaikan tertinggi pada Januari 2015, dibandingkan dengan sektor lain dalam Bursa Efek 
Indonesia (BEI). Target penguatan indeks sektor trade, services, \& investment di tahun 2015 diprediksi bisa mencapai 26\%. (http://market.bisnis.com). Namun pada tahun 2017 sektor trade, service, and investment mencatat kinerja underform terhadap IHSG. Sektor perdagangan dan jasa hanya tumbuh 1,54 $\%$. Saham didefinisikan sebagai tanda penyertaan atau kemilikan seseorang atau badan dalam suatu perusahaan. Saham merupakan salah satu alternatif investasi yang banyak diminati investor karena keuntungan yang diperoleh lebih besar dan dana yang dibutuhkan oleh investor untuk melakukan investasi tidak terlalu besar apabila dibandingkan dengan obligasi. Tujuan diterbitkannya saham oleh perusahaan bagi investor adalah untuk memaksimalkan kesejahteraan pemegang saham yang dilakukan dengan memaksimalkan nilai perusahaan yang dicerminkan melalui harga saham perusahaan tersebut.

Harga saham merupakan salah satu indikator yang menunjukkan minat dari investor untuk memiliki saham suatu perusahaan. Jika suatu perusahaan memiliki harga saham yang mengalami kenaikan atau cenderung stabil, maka investor menilai bahwa perusahaan tersebut memiliki prestasi baik. Seorang investor selalu mengharapkan harga saham yang stabil dan mempunyai pola pergerakan yang cenderung naik dari waktu ke waktu, akan tetapi pada kenyataannya harga saham cenderung berfluktuasi.

Berfluktuasinya harga saham menjadi risiko tersendiri bagi investor. Sebab itu, investor harus memahami hal apa saja yang dapat dipertimbangkan oleh investor untuk pengambilan keputusan investasi.

Salah satu rasio pasar yang dapat dipertimbangkan investor untuk pengambilan keputusan investasi adalah Dividend Payout Ratio (DPR). Dividend Payout Ratio (DPR) adalah rasio yang membahas tentang besarnya dividen yang dibagikan kepada pemegang saham. atau dalam arti lain dividen adalah bagian keuntungan yang diterima oleh pemegang saham dari suatu perusahaan. Dividend Payout Ratio merupakan perbandingan antara dividen yang dibayarkan dengan laba bersih. Semakin tinggi Dividend Payout Ratio, akan menguntungkan bagi investor selaku pemegang saham. Dividen yang dibagikan semakin besar, maka harga saham perusahaan akan semakin tinggi. Hal ini terjadi karena pembagian dividen dapat mengurangi ketidakpastian yang dihadapi oleh investor.

Current Ratio (CR) adalah rasio yang membahas perbandingan antara aktiva lancar dengan hutang lancar, aktiva lancar adalah aset yang sehari-hari dioperasikan perusahaan. Dalam aktiva lancar harus ditentukan berapa kas yang harus tersedia agar tidak terlalu berlebihan atau tidak kekurangan. Kas yang berlebihan merupakan suatu kegagalan untuk mendatangkan penghasilkan, sementara jumlah kas yang berkurang berakibat pada kegagalan membayar kewajiban pada waktunya dan akan meningkatkan biaya yang harus ditanggung pada pemenuhan kebutuhan dana berikutnya termasuk biaya pinalti. Semakin tinggi nilai current ratio menunjukkan semakin baik kemampuan perusahaan dalam membayar kewajiban jangka pendeknya. Hal ini akan memperkecil risiko yang akan terjadi, sehingga kaitannya berakibat pada permintaan terhadap saham perusahaan akan naik dan mendorong naiknya harga saham perusahaan tersebut. 
Net Profit Margin (NPM) mengukur tipis atau tebalnya laba perusahaan. Semakin tinggi nilai NPM menandakan bahwa perusahaan tersebut semakin efisien operasionalnya. Perusahaan dapat menekan biaya-biaya yang tidak perlu, sehingga perusahaan mampu memaksimalkan laba bersih yang didapatkan. Perusahaan akan lebih cepat tumbuh menjadi perusahaan dengan ekuitas yang besar. Pertumbuhan ini dikarenakan perusahaan yang selalu mencatatkan laba bersih tinggi, dan laba bersih tersebut akan masuk sebagai saldo laba yang nantinya semakin menambah ekuitas perusahaan. Perusahaan yang mampu menghasilkan labanya dengan baik dapat meningkatkan harga saham.

\subsection{Rumusan Masalah}

1. Bagaimana pengaruh Dividend Payout Ratio terhadap Harga Saham pada Perusahaan Sektor Trade, Service, and Investmentyang terdaftar di Bursa Efek Indonesia periode 2014-2018 ?

2. Bagaimana pengaruhCurrent Ratioterhadap Harga Saham pada Perusahaan Sektor Trade, Service, and Investmentyang terdaftar di Bursa Efek Indonesia periode 2014-2018 ?

3. Bagaimana pengaruh Net Profit Marginterhadap Harga Saham pada Perusahaan Sektor Trade, Service, and Investmentyang terdaftar di Bursa Efek Indonesia periode 2014-2018?

4. Bagaimana pengaruhDividend Payout Ratio, Current Ratio, dan Net Profit Margin secara simultanterhadap Harga Saham pada Perusahaan Sektor Trade, Service, and Investmentyang terdaftar di Bursa Efek Indonesia periode 2014-2018?

\section{KAJIAN LITERATUR}

\subsection{Teori Pengaruh Variabel DPR Terhadap Harga Saham}

Menurut Wiyono dan Kusuma (2017:70), DPR menentukan besarnya dividen yang diterima oleh pemilik saham dan besarnya dividen ini secara positif dapat mempengaruhi harga saham terutama pada pasar modal yang didominasi investor dengan karateristik strategi mengejar dividen sebagai target utama. Menurut Sudana (2015:193), dividen yang dibagikan semakin besar maka harga pasar saham atau nilai perusahaan akan semakin tinggi, hal ini dikarenakan para investor lebih menyukai dividend yield dibandingkan dengan capital gains yang disebut dengan teori bird in the hand.

Menurut Mulyawan (2015:263), kebijakan dividen berpengaruh positif terhadap nilai saham, melalui penciptaan keseimbangan antara dividen saat ini dan laba ditahan sehingga mampu memaksimalkan nilai saham.

\subsection{Teori Pengaruh Variabel CR Terhadap Harga Saham}

Menurut Subramanyam (2011:241), kurangnya likuiditas menghalangi perusahaan untuk memperoleh keuntungan dari diskon atau kesempatan mendapatkan keuntungan. Ketidakmampuan perusahaan untuk memenuhi kewajiban lancarnya merupakan masalah likuiditas yang lebih ekstrem. 
Masalah ini dapat mengarah pada penjualan investasi dan aset lainnya dipaksakan dan kemungkinan yang paling parah mengarah pada insolvabilitas dan kebangkrutan. Bagi pemegang saham perusahaan, kurangnya likuiditas dapat meramalkan hilangnya kendali pemilik atau kerugian investasi modal.

\subsection{Teori Pengaruh Variabel NPM Terhadap Harga Saham}

Menurut Sudana (2015:73), semakin tinggi profit margin akan meningkatkan kemampuan perusahaan menghasilkan dana secara internal dan akan meningkatkan pertumbuhan berkelanjutan perusahaan. Menurut Kamaludin dan Indriani (2012:321), kenaikan nilai perusahaan terjadi karena pembayaran bunga atas hutang merupakan pengurangan pajak oleh karena itu laba operasi yang diterima investor akan lebih besar. Dampak selanjutnya karena laba yang diterima lebih besar, nilai perusahaan juga akan lebih besar. Menurut Brigham dan Houston (2012: 150), jika rasio profitabilitas terlihat baik, dan jika kondisi ini berjalan terus menerus secara stabil, maka harga saham kemungkinan tinggi sesuai dengan yang diperkirakan, dan manajemen telah melakukan pekerjaannya dengan baik sehingga sebaiknya mendapat imbalan.

\section{$2.4 \quad$ Kerangka Konseptual}

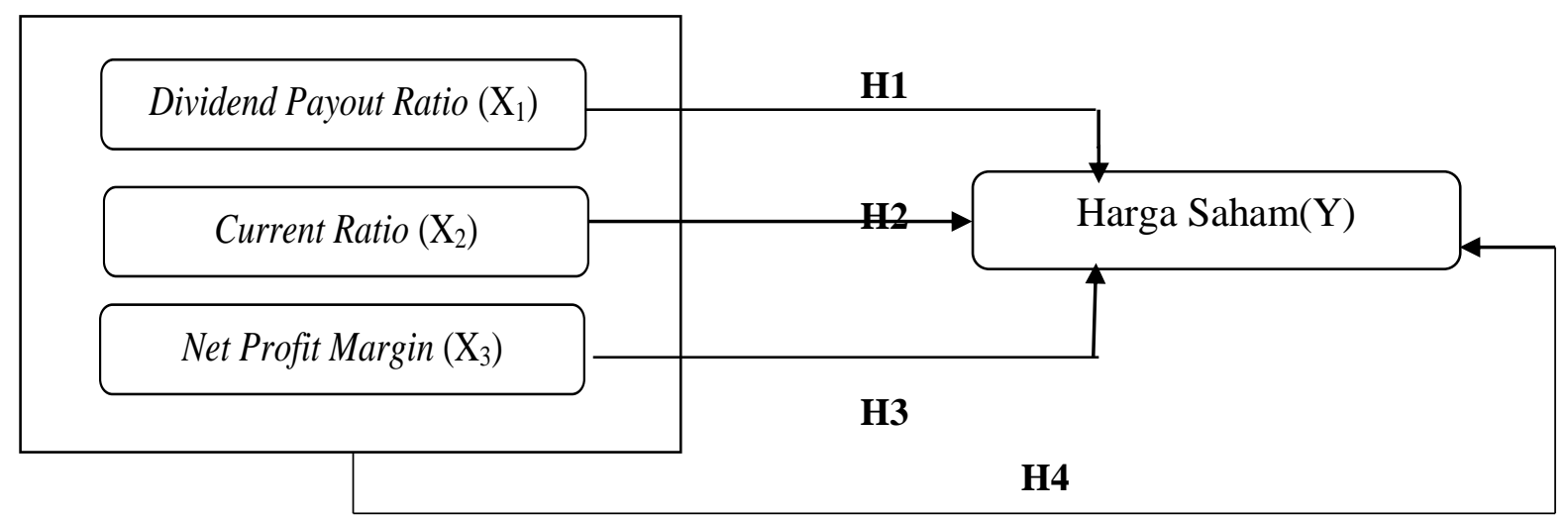

Gambar 1. Kerangka Konseptual

\section{METODE}

\subsection{Pendekatan Penelitian}

Pendekatan penelitian yang digunakan adalah pendekatan kuantitatif. Menurut Sugiyono (2017:8), penelitian kuantitatif dapat diartikan sebagai metode yang berlandaskan pada filsafat positivisme, digunakan untuk meneliti pada populasi atau sampel tertentu, pengumpulan data menggunakan instrumen penelitian, analisis data bersifat kuantitatif/statistik, dengan tujuan untuk menguji hipotesis yang telah ditetapkan

\subsection{Populasi}

Menurut Sugiyono (2017:80), Populasi adalah wilayah generalisasi yang terdiri atas obyek/subyek yang mempunyai kualitas dan karakterisitik tertentu yang ditetapkan oleh peneliti untuk 
dipelajari dan kemudian ditarik kesimpulannya.Populasi yang digunakan dalam penelitian ini adalah laporan keuangan tahunan Perusahaan Sektor Trade, Service, and Investment yang terdaftar di Bursa Efek Indonesia pada periode 2014-2018 berjumlah 132 perusahaan yang terdiri dari sub sektor perdagangan besar barang produksi; subsektor perdagangan eceran; subsektor restoran; subsektor printing \& media; subsektor kesehatan; jasa komputer \& perangkatnya; subsektor perusahaan investasi; dan subsektor lainnya.

\subsection{Sampel}

Menurut Sugiyono (2017:81), Sampel adalah bagian dari jumlah dan karakteristik yang dimiliki oleh populasi tersebut. Menurut Sugiyono (2017:84), Nonprobability Sampling adalah teknik pengambilan sampel yang tidak memberi peluang/ksempatan sama bagi setiap unsur atau anggota populasi untuk dipilih menjadi sampel. Sampel dipilih dengan menggunakan teknik Sampling Purposive. Menurut Sugiyono (2017:85), Sampling Purposive adalah teknik penentuan sampel dengan pertimbangan tertentu. Sampel penelitian ini adalah laporan keuangan Perusahaan Sektor Trade, Service, and Investment periode 2014-2018.

Kriteria penentuan sampel perusahaan dalam penelitian ini adalah sebagai berikut :

1. Perusahaan Sektor Trade, Service, and Investment yang terdaftar di Bursa Efek Indonesia (BEI) pada periode 2014-2018.

2. Perusahaan Sektor Trade, Service, and Investment yang lengkap mempublish laporan keuangan secara lengkap di Bursa Efek Indonesia periode 2014-2018.

3. Perusahaan Sektor Trade, Service, and Investment yang mempublish laporan keuangan dalam satuan rupiah di Bursa Efek Indonesia (BEI) pada periode 2014-2018.

4. Perusahaan Sektor Trade, Service, and Investment yang memiliki laba positif di Bursa Efek Indonesia (BEI) pada periode 2014-2018.

5. Perusahaan Sektor Trade, Service, and Investment yang membagikan dividen tunai di Bursa Efek Indonesia (BEI) pada periode 2014-2018.

Perusahaan Sektor Trade, Service, and Investment yang terdaftar di Bursa Efek Indonesia pada periode 2014-2018 berjumlah 132 perusahaan. dari 132 perusahaan tersebut, peneliti telah menentukan kriteria yang diambil untuk di olah dan di teliti. Setelah melewati berbagai kriteria, jumlah perusahaan yang akan diteliti menjadi 17 perusahaan dan perusahaan-perusahaan ini di teliti selama 5 tahun sehingga jumlah sampel menjadi berjumlah 85 .

\subsection{Definisi Operasional Variabel Penelitian}

Definisi operasional untuk masing-masing variabel bebas dan variabel terikat dapat dilihat pada tabel berikut. 
Tabel 1.

Identifikasi dan Definisi Operasional Variabel Penelitian

\begin{tabular}{|c|c|c|c|}
\hline $\begin{array}{l}\text { Variabel } \\
\text { Penelitian }\end{array}$ & Definisi Variabel & Indikator Variabel & $\begin{array}{c}\text { Skala } \\
\text { Pengukuran }\end{array}$ \\
\hline $\begin{array}{c}\text { Dividend } \\
\text { Payout Ratio } \\
\left(\mathrm{X}_{1}\right)\end{array}$ & $\begin{array}{l}\text { Dividend Payout Ratio } \\
\text { adalah rasio yang mengukur } \\
\text { seberapa besar bagian laba } \\
\text { bersih setelah pajak yang } \\
\text { dibayarkan sebagai dividen } \\
\text { kepada para pemegang } \\
\text { saham.(Sudana, 2015:26) }\end{array}$ & $\begin{array}{l}\mathrm{DPR}=\frac{\text { Dividend }}{\text { Earning After Taxes }} \\
\text { (Sudana,2015:26) }\end{array}$ & Rasio \\
\hline $\begin{array}{c}\text { Current Ratio } \\
\qquad\left(\mathrm{X}_{2}\right)\end{array}$ & $\begin{array}{l}\text { rasio lancar atau current } \\
\text { ratio adalah rasio yang biasa } \\
\text { digunakan untuk mengukur } \\
\text { kemampuan perusahaan } \\
\text { memenuhi liabilitas jangka } \\
\text { pendek yang akan jatuh } \\
\text { tempo dalam waktu satu } \\
\text { tahun.(Murhadi, 2015:57) }\end{array}$ & $\begin{array}{l}\mathrm{CR}=\frac{\text { Current Assets }}{\text { Current Liabilities }} \\
\text { (Murhadi, 2015:57) }\end{array}$ & Rasio \\
\hline $\begin{array}{c}\text { Net Profit } \\
\text { Margin }\left(\mathrm{X}_{3}\right)\end{array}$ & $\begin{array}{l}\text { profit margin adalah rasio } \\
\text { yang menghitung sejauh } \\
\text { mana kemampuan } \\
\text { perusahaan menghasilkan } \\
\text { laba bersih pada tingkat } \\
\text { penjualan tertentu. } \\
\text { Hanafi dan Halim (2016:81) }\end{array}$ & $\begin{array}{l}\text { Profit Margin }=\frac{\text { Laba Bersih }}{\text { Penjualan }} \\
\text { Hanafi dan Halim } \\
(2016: 81)\end{array}$ & Rasio \\
\hline $\begin{array}{l}\text { Harga Saham } \\
\text { (Y) }\end{array}$ & $\begin{array}{l}\text { Close atau closing price } \\
\text { menunjukkan harga } \\
\text { penutupan suatu saham. } \\
\text { Darmadji dan Fakhruddin } \\
(2011: 102)\end{array}$ & $\begin{array}{l}\text { Darmadji dan Fakhruddin } \\
(2011: 102)\end{array}$ & Rasio \\
\hline
\end{tabular}

\subsection{Teknik Analisis data}

\section{Uji Asumsi Klasik}

\section{Uji Normalitas}

Menurut Ghozali (2016:154), uji normalitas bertujuan untuk menguji apakah dalam model regresi, variabel pengganggu atau residual memiliki distribusi normal. Ada dua cara untuk mendeteksi apakah residual berdistribusi normal atau tidak, yaitu analisis grafik dan uji statistik.

\section{Uji Multikolinieritas}

Menurut Ghozali (2016:103), Uji Multikolinieritas bertujuan untuk menguji apakah model regresi ditemukan adanya kolerasi antar variabel bebas (independen). Model regresi yang baik seharusnya tidak terjadi korelasi antara variabel independen. 


\section{Uji Autokolerasi}

Menurut Ghozali (2016:107-108), uji Autokorelasi bertujuan menguji apakah dalam model regresi linear ada korelasi antara kesalahan pengganggu pada periode t dengan kesalahan pengganggu pada periode t-1 (sebelumnya).

\section{Uji Heteroskedastisitas}

Menurut Ghozali (2016:134), Uji Heteroskedastisitas bertujuan menguji apakah dalam model regresi terjadi ketidaksamaan variance dari residual suatu pengamatan ke pengamatan lain.

\subsection{Model Analisis Data Penelitian}

Analisis data dalam penelitian ini menggunakan analisis regresi linear berganda yang bertujuan untuk mengetahui besarnya pengaruh Dividend Payout Ratio, Current Ratio, dan Net Profit Margin terhadap Harga Saham. Persamaan analisis regresi linear berganda secara umum dalam menguji hipotesishipotesis penelitian ini sebagai berikut :

$$
Y=a+b_{1} X_{1}+b_{2} X_{2}+b_{3} X_{3}+\varepsilon
$$

Dimana; Y: Harga Saham, a: Konstanta, $\mathrm{b}_{1}, \mathrm{~b}_{2}, \mathrm{~b}_{3}$ : Koefisien Regresi, $\mathrm{X}_{1}$ : Dividend Payout Ratio (DPR), $\mathrm{X}_{2}$ : Current Ratio (CR), $\mathrm{X}_{3}:$ Net Profit Margin (NPM), $\varepsilon$ : Persentase Kesalahan (5\%)

\section{Koefisien Determinasi Hipotesis}

Menurut Ghozali (2016:95), koefisien determinasi $\left(\mathrm{R}^{2}\right)$ pada intinya mengukur seberapa jauh kemampuan model dalam menerangkan variasi variabel dependen. Nilai koefisien determinasi adalah antara nol dan satu. Nilai $\mathrm{R}^{2}$ yang kecil berarti kemampauan variabel-variabel independen dalam menjelaskan variasi variabel dependen amat terbatas. Nilai yang mendekati satu berarti variabel-variabel independen memberikan hampir semua informasi yang dibutuhkan untuk memprediksi variasi variabel dependen.

\section{Pengujian Hipotesis Secara Parsial (Uji t)}

Menurut Ghozali (2016:97), uji statistik t pada dasarnya menunjukkan seberapa jauh pengaruh satu variabel penjelas/independen secara individual dalam menerangkan variasi variabel dependen.Hipotesis no $\left(\mathrm{H}_{0}\right)$ yang hendak diuji adalah apakah suatu parameter $\left(\mathrm{b}_{\mathrm{i}}\right)$ sama dengan nol.

\section{Pengujian Hipotesis Secara Simultan (Uji F)}

Menurut Ghozali (2016:96), uji F menguji jointhipotesia bahwa b1, b2, dan b3 secara simultan sama dengan nol. 


\section{HASIL DAN DISKUSI}

Tabel 2.

Statistik Deskriptif

\begin{tabular}{|l|r|r|r|r|r|}
\hline & N & \multicolumn{1}{|c|}{ Minimum } & Maximum & \multicolumn{1}{c|}{ Mean } & \multicolumn{1}{|c|}{ Std. Deviation } \\
\hline DPR & 85 &, 0344 & 2,0754 &, 361722 &, 3327946 \\
CR & 85 &, 2744 & 9,7169 & 2,257176 & 1,7533630 \\
NPM & 85 &, 0053 &, 3598 &, 108285 &, 0973719 \\
HargaSaham & 85 & 52 & 17600 & 1620,32 & 3063,400 \\
Valid N (listwise) & 85 & & & & \\
\hline
\end{tabular}

Sumber : Data Output SPSS, 2019

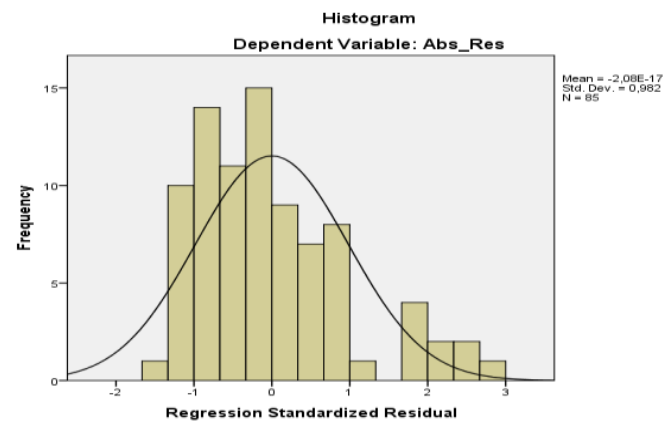

Gambar 1.

Grafik Histogram (Sesudah Transformasi)

Sumber : Data Output SPSS, 2019

\section{UJi Normalitas}

Setelah dilakukan transformasi dengan LN plot grafik histogram menunjukkan pola distribusi yang berbentuk lonceng tanpa melenceng (skewness) kekiri dan berdistribusinormal.

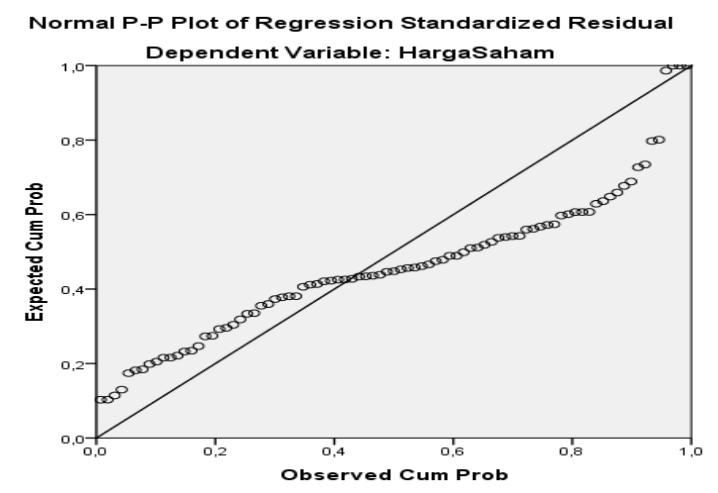

Gambar 2.

Grafik Normal P-Plot (Sesudah Transformasi)

Sumber : Data Output SPSS, 2019 
Setelah di transformasi menggunakan LN grafik normal p-plot menunjukkan gambaran pola data yang baik, dimana dapat dilihat data menyebar disekitar garis diagonal dan mengikuti arah garis diagonal, hal ini menunjukkan pola distribusi normal dan memenuhi asumsi normalitas.

Tabel 3.

Hasil Uji Normalitas Kolmogrov-Smirnov Test (Sesudah Transformasi) One-Sample Kolmogorov-Smirnov Test

\begin{tabular}{|c|c|c|}
\hline & & Unstandardized Residual \\
\hline $\mathrm{N}$ & & 85 \\
\hline Normal Parameters ${ }^{\mathrm{a}, \mathrm{b}}$ & Mean & ,0000000 \\
\hline & Std. Deviation & ,93832896 \\
\hline Most Extreme Differences & Absolute &, 081 \\
\hline & Positive &, 052 \\
\hline & Negative &,- 081 \\
\hline Test Statistic & & ,081 \\
\hline Asymp. Sig. (2-tailed) & &, $200^{\mathrm{c}, \mathrm{d}}$ \\
\hline
\end{tabular}

a. Test distribution is Normal.

b. Calculated from data.

c. Lilliefors Significance Correction.

d. This is a lower bound of the true significance.

Sumber : Data Output SPSS, 2019

\section{Uji Multikolonieritas}

Uji multikolonieritas bertujuan untuk menguji apakah dalam model regresi ditemukan adanya korelasi antar variabel independen. Pada model regresi yang baik seharusnya tidak terjadi korelasi antar variabel independen. Pengujian multikolonieritas dilakukan dengan melihat Tolerance dan Variance Inflation Factor (VIF) antar variabel independen. Dengan kriteria nilai Tolerance> 0,1 dan nilai VIF < 10.

Tabel 4.

Hasil Uji Multikolinearitas

Coefficients $^{\mathrm{a}}$

\begin{tabular}{|c|c|c|c|c|c|c|c|c|}
\hline \multirow[b]{2}{*}{ Mod } & & \multicolumn{2}{|c|}{$\begin{array}{c}\text { Unstandardized } \\
\text { Coefficients }\end{array}$} & \multirow{2}{*}{\begin{tabular}{|c|}
$\begin{array}{c}\text { Standardized } \\
\text { Coefficients }\end{array}$ \\
Beta \\
\end{tabular}} & \multirow[b]{2}{*}{$\mathrm{T}$} & \multirow[b]{2}{*}{ Sig. } & \multicolumn{2}{|c|}{ Collinearity Statistics } \\
\hline & & $\mathrm{B}$ & Std. Error & & & & Tolerance & VIF \\
\hline \multirow[t]{4}{*}{1} & (Constant) & 594,277 & 578,792 & & 1,027 & ,308 & & \\
\hline & DPR & 1501,684 & 902,052 & ,163 & 1,665 & , 100 & ,973 & 1,028 \\
\hline & CR & $-514,793$ & 184,559 &,- 295 & $-2,789$ & ,007 & ,837 & 1,194 \\
\hline & NPM & 15189,862 & 3326,528 & ,483 & 4,566 &, 000 & ,836 & 1,197 \\
\hline
\end{tabular}

a. Dependent Variable: HargaSaham

Sumber : Data Output SPSS, 2019

Nilai tolarance semua variabel independen $>0,10$ yaitu Dividend Payout Ratio $\left(\mathrm{X}_{1}\right)=0,973$ $;$ Current Ratio $\left(\mathrm{X}_{2}\right)=0,837 ;$ Net Profit Margin $\left(\mathrm{X}_{3}\right)=0,836$. Sedangkan VIF $<10$ yaitu Dividend Payout 
Ratio $\left(\mathrm{X}_{1}\right)=1,028 ;$ Current Ratio $\left(\mathrm{X}_{2}\right)=1,194 ;$ Net Profit Margin $\left(\mathrm{X}_{3}\right)=1,197$. Sehingga dapat disimpulkan bahwa dalam model regresi tidak terjadi multikolonieritas.

\section{Uji Autokorelasi}

Uji autokolerasi bertujuan untuk menguji apakah dalam model regresi linear ada korelasi antara kesalahan pengganggu pada periode $\mathrm{t}$ dengan kesalahan pada periode t-1 (sebelumnya).Uji autokolerasi dapat dilakukan dengan Durbin-Watson (DW).

Tabel 5.

Hasil Uji Autokorelasi (Sesudah Transformasi)

Model Summary ${ }^{\mathrm{b}}$

\begin{tabular}{|l|r|r|r|r|r|}
\hline Model & \multicolumn{1}{|c|}{$\mathrm{R}$} & R Square & Adjusted R Square & Std. Error of the Estimate & Durbin-Watson \\
\hline 1 &, $548^{\mathrm{a}}$ &, 301 &, 275 &, 95555 & 2,388 \\
\hline
\end{tabular}

a. Predictors: (Constant), LN_NPM, LN_DPR, LN_CR

b. Dependent Variable: LN_HargaSaham

\section{Sumber : Data Output SPSS, 2019}

Diketahui nilai statistik Durbin-Watson setelah transformasi menggunakan LN adalah 2,388. Sedangkan k $=3$ (variabel bebas, tidak termasuk variabel terikat) dan $n=85$. Sementara nilai $d_{L}=1,575$ dan $d_{u}=1,721$.

Dengan melihat kriteria pengambilan keputusan pada Durbin-Watson maka nilai $4-\mathrm{d}_{\mathrm{u}} \leq \mathrm{d} \leq 4-\mathrm{d}_{\mathrm{l}}(2,279 \leq$ $2,388 \leq 2,425)$.Maka diperoleh kesimpulan tidak tejadi autokorelasi negatif dalam data penelitian.

\section{Uji Heterokedastisitas}

Uji heterokedastisitas bertujuan untuk menguji apakah dalam model regresi terjadi ketidaksamaan variance dari residual satu pengamatan ke pengamatan lain

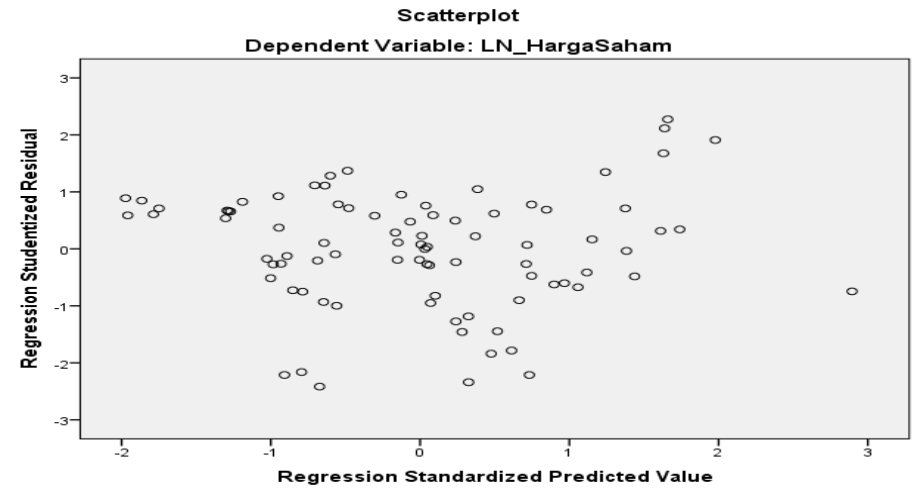

Gambar 3.

\section{Hasil Grafik Scatterplot (Sesudah Transformasi)}

\section{Sumber : Data Output SPSS, 2019}

Berdasarkan gambar diatas dapat dilihat bahwa titik-titik menyebar secara acak baik diatas maupun dibawah angka nol pada sumbu Y. Maka dapat disimpulkan pada sampel tidak terjadi gejala heterokedastisitas. 
Tabel 6.

Hasil Uji Glejser (Sesudah Transformasi)

Coefficients $^{\mathrm{a}}$

\begin{tabular}{|c|c|c|c|c|c|c|}
\hline \multirow{2}{*}{\multicolumn{2}{|c|}{ Model }} & \multicolumn{2}{|c|}{ Unstandardized Coefficients } & \multirow{2}{*}{$\begin{array}{l}\text { Standardized } \\
\text { Coefficients } \\
\text { Beta }\end{array}$} & \multirow[b]{2}{*}{$\mathrm{t}$} & \multirow[b]{2}{*}{ Sig. } \\
\hline & & $\mathrm{B}$ & Std. Error & & & \\
\hline \multirow[t]{4}{*}{1} & (Constant) & 1,161 & ,235 & & 4,936 & 000 \\
\hline & LN_DPR &, 121 & ,068 & ,193 & 1,775 &, 080 \\
\hline & LN_CR &,- 215 & ,111 &,- 231 & $-1,941$ &, 056 \\
\hline & LN_NPM & 047 &, 065 & ,086 & ,718 & ,475 \\
\hline
\end{tabular}

a. Dependent Variable: Abs_Res

\section{Sumber : Data Output SPSS, 2019}

Berdasarkan hasil uji glejser diatas menunjukkan nilai signifikan dari variabel Dividend Payout Ratio yaitu 0,080;Current Ratioyaitu 0,056 ; Net Profit Margin yaitu 0,475. Karena nilai signifikan dari ketiga variabel lebih besar dari 0,05 maka dapat disimpulkan bahwa hasil uji glejser menunjukkan tidak terjadi masalah heterokedastisitas.

\section{Analisis Regresi Linear Berganda}

Pengujian hipotesis yang digunakan dalam penelitian ini adalah dengan menggunakan analisis regresi linear berganda.

Tabel 7.

Persamaan Regresi Linear Berganda

Coefficients $^{\mathrm{a}}$

\begin{tabular}{|c|c|c|c|c|c|c|}
\hline \multirow{2}{*}{\multicolumn{2}{|c|}{ Model }} & \multicolumn{2}{|c|}{ Unstandardized Coefficients } & $\begin{array}{l}\text { Standardized } \\
\text { Coefficients }\end{array}$ & \multirow[b]{2}{*}{$\mathrm{t}$} & \multirow[b]{2}{*}{ Sig. } \\
\hline & & B & Std. Error & Beta & & \\
\hline \multirow[t]{4}{*}{1} & (Constant) & 8,755 & ,398 & & 22,012 &, 000 \\
\hline & LN_DPR & , 185 & ,115 & , 152 & 1,610 &, 111 \\
\hline & LN_CR &,- 379 & , 187 &,- 209 & $-2,023$ & ,046 \\
\hline & LN_NPM & (599 & , 110 & ,563 & 5,421 & , 000 \\
\hline
\end{tabular}

a. Dependent Variable: LN_HargaSaham

Sumber : Data Output SPSS, 2019

Berdasarkan Tabel IV.11 diatas maka diperoleh persamaan regresi linear berganda sebagai berikut :

LN_HS = 8,755 + 0,185LN_DPR - 0,379LN_CR+ 0,599LN_NPM 
Koefisien persamaan regresi liniear berganda diatas dapat diartikan sebagai berikut :

a. Nilai konstanta sebesar 8,755 menunjukkan apabila nilai DPR, CR, dan NPM dianggap konstan, maka nilai Harga Saham pada perusahaan sektor trade, service, and investment sebesar 8,755.

b. Nilai koefisien DPR sebesar 0,185 menunjukkan bahwa setiap peningkatan DPR satu kali akan diikuti peningkatan Harga Saham sebesar 0,185 dengan asumsi semua variabel independen dianggap nol.

c. Nilai koefisien CR sebesar -0,379 menunjukkan bahwa setiap peningkatan CR satu kali akan diikuti penurunan Harga Saham sebesar 0,379 dengan asumsi semua variabel independen dianggap nol.

d. Nilai koefisien NPM sebesar 0,599 menunjukkan bahwa setiap peningkatan NPM satu kali akan diikuti peningkatan Harga Saham sebesar 0,599 dengan asumsi semua variabel independen dianggap nol.

\section{Koefisien Determinasi}

Koefisien determinasi digunakan untuk mengukur seberapa besar kemampuan pengaruh variabel bebas dapat menjelaskan variabel terikat. Koefisien determinasi $\left(\mathrm{R}^{2}\right)$ semakin besar maka semakin baik kemampuan variabel bebas $(\mathrm{X})$ menerangkan variabel terikat $(\mathrm{Y})$ berikut ini nilai koefisien determinasi:

Tabel 8.

\section{Koefisien Determinasi} Model Summary ${ }^{\mathrm{b}}$

\begin{tabular}{|l|r|r|r|r|r|}
\hline Model & \multicolumn{1}{|c|}{$\mathrm{R}$} & R Square & Adjusted R Square & Std. Error of the Estimate & Durbin-Watson \\
\hline 1 &, $548^{\mathrm{a}}$ &, 301 &, 275 &, 95555 & 2,388 \\
\hline
\end{tabular}

a. Predictors: (Constant), LN_NPM, LN_DPR, LN_CR

b. Dependent Variable: LN_HargaSaham

\section{Sumber : Data Output SPSS, 2019}

Pada tabel diatas, hasil analisa regresi dapat dilihat nilai $\mathrm{R}$ Square sebesar 0,301 menunjukkan bahwa korelasi atau keeratan hubungan DPR, CR, dan NPM sebesar 30,1\%. Nilai Adjusted R Square sebesar 0,275 mengindikasikan bahwa variasi DPR, CR, dan NPM menjelaskan variasi variabel terhadap Harga Saham sebesar 27,5 \% sedangkan sisanya 72,7 \% dijelaskan oleh faktor-faktor lain diluar variabel yang belum diteliti.

\section{Pengujian Hipotesis Secara Parsial (Uji t)}

Uji t dilakukan untuk menunjukkan seberapa jauh pengaruh satu variabel independen secara individual terhadap variabel dependen. 


\section{Tabel 9.}

Hasil Uji Statistik t

Coefficients $^{\mathrm{a}}$

\begin{tabular}{|c|c|c|c|c|c|c|c|c|}
\hline \multirow{2}{*}{\multicolumn{2}{|c|}{ Coefficients ${ }^{\mathrm{a}}$ Model }} & \multicolumn{2}{|c|}{$\begin{array}{c}\text { Unstandardized } \\
\text { Coefficients }\end{array}$} & \multirow{2}{*}{$\begin{array}{c}\begin{array}{c}\text { Standardized } \\
\text { Coefficients }\end{array} \\
\text { Beta }\end{array}$} & \multirow[b]{2}{*}{$\mathrm{T}$} & \multirow[b]{2}{*}{ Sig. } & \multicolumn{2}{|c|}{ Collinearity Statistics } \\
\hline & & $\mathrm{B}$ & Std. Error & & & & Tolerance & VIF \\
\hline \multirow[t]{4}{*}{1} & (Constant) & 8,755 &, 398 & & 22,012 & ,000 & & \\
\hline & LN_DPR &, 185 & ,115 &, 152 & 1,610 & ,111 & ,967 & 1,034 \\
\hline & LN_CR &,- 379 & ,187 &,- 209 & $-2,023$ & ,046 & ,806 & 1,241 \\
\hline & LN_NPM & ,599 &, 110 &, 563 & 5,421 & ,000 &, 800 & 1,249 \\
\hline
\end{tabular}

a. Dependent Variable: LN_HargaSaham

Sumber : Data Output SPSS, 2019

Berdasarkan hasil dari Tabel IV.15 setelah transformasi menggunakan LN dapat dilihat bahwa :

1. Variabel DPR secara parsial memiliki $t_{\text {hitung }}$ sebesar 1,610 dan nilai $t_{\text {tabel }}$ sebesar 1,993, maka $t_{\text {hitung }}<t_{\text {tabel }}(1,610<1,993)$ dengan nilai signifikan $0,111>0,05$ hasil tersebut menunjukkan bahwa $\mathrm{H}_{\mathrm{a}}$ ditolak dan $\mathrm{H}_{\mathrm{o}}$ diterima yang artinya secara parsial DPR tidak berpengaruh signifikan terhadap Harga Saham pada perusahaan sektor trade, service, and investment yang terdaftar di BEI periode 2014-2018.

2. Variabel CR secara parsial memiliki thitung sebesar $-2,023$ dan nilai tabel sebesar 1,993, maka $\mathrm{t}_{\text {hitung }}<\mathrm{t}_{\text {tabel }}(-2,023<1,993)$ dengan nilai signifikan $0,046<0,05$ hasil tersebut menunjukkan bahwa $\mathrm{H}_{\mathrm{a}}$ ditolak dan $\mathrm{H}_{\mathrm{o}}$ ditolak yang artinya secara parsial $\mathrm{CR}$ tidak berpengaruh signifikan terhadap Harga Saham pada perusahaan sektor trade, service, and investment yang terdaftar di BEI periode 2014-2018.

3. Variabel DPR secara parsial memiliki $t_{\text {hitung }}$ sebesar 5,421 dan nilai $t_{\text {tabel }}$ sebesar 1,993, maka $t_{\text {hitung }}>t_{\text {tabel }}(5,421<1,993)$ dengan nilai signifikan $0,000<0,05$ hasil tersebut menunjukkan bahwa $\mathrm{H}_{\mathrm{a}}$ diterima dan $\mathrm{H}_{\mathrm{o}}$ ditolak yang artinya secara parsial NPM berpengaruh signifikan terhadap Harga Saham pada perusahaan sektor trade, service, and investment yang terdaftar di BEI periode 2014-2018.

\section{Pengujian Hipotesis Secara Simultan (Uji F)}

Uji F digunakan untuk mengetahui apakah semua variabel independen yang dimasukkan dalam model mempunyai pengaruh secara simultan terhadap variabel dependen. 
Tabel 10.

Hasil Uji Statistik F

ANOVA $^{\mathrm{a}}$

\begin{tabular}{|ll|r|r|r|r|r|}
\hline \multicolumn{1}{|l|}{} & \multicolumn{1}{|c|}{$\begin{array}{c}\text { Sum of } \\
\text { Model }\end{array}$} & Squares & df & Mean Square & F & \multicolumn{2}{|c|}{ Sig. } \\
\hline 1 & Regression & 31,785 & 3 & 10,595 & 11,604 &, $000^{\mathrm{b}}$ \\
& Residual & 73,959 & 81 &, 913 & & \\
& Total & 105,744 & 84 & & & \\
\hline
\end{tabular}

a. Dependent Variable: LN_HargaSaham

b. Predictors: (Constant), LN_NPM, LN_DPR, LN_CR

Sumber : Data Output SPSS, 2019

Berdasarkan tabel di atas diketahui nilai signifikan untuk pengaruh DPR, CR, dan NPM secara simultan terhadap Harga Saham adalah sebesar 0,000 $<0,05$ dan nilai $F_{\text {hitung }} 11,604>f_{\text {tabel }}$ 2,72 sehingga dapat disimpulkan bahwa hipotesis keempat $\left(\mathrm{H}_{4}\right)$ diterima yang berarti terdapat pengaruh DPR, CR, dan NPM secara simultan terhadap Harga Saham pada perusahaan sektor Trade, Services, and Investment di BEI pada periode 2014-2018.

\section{KESIMPULAN}

Secara parsial variabel kebijakan dividend memiliki nilai $t_{\text {hitung }}<t_{\text {tabel }}(1,610<1,993)$ dengan nilai signifikan $0,111>0,05$. Hasil tersebut menunjukkan bahwa $\mathrm{H}_{\mathrm{a}}$ ditolak dan $\mathrm{H}_{0}$ diterima yang artinya bahwa secara parsial kebijakan dividen tidak berpengaruh terhadap harga saham. Untuk variabel likuiditas memiliki nilai $-\mathrm{t}_{\text {hitung }}<\mathrm{t}_{\text {tabel }}(-2,023<-1,993)$ dengan nilai signifikan $0,046<0,05$. Hasil tersebut menunjukkan bahwa $\mathrm{H}_{\mathrm{a}}$ ditolak dan $\mathrm{H}_{0}$ ditolak yang artinya bahwa secara parsial likuiditas tidak berpengaruh terhadap harga saham. Untuk variabel profitabilitas memiliki nilai $t_{\text {hitung }}>t_{\text {tabel }}(5,421>$ 1,993) dengan nilai signifikan $0,000<0,05$. Hasil tersebut menunjukkan bahwa $\mathrm{H}_{\mathrm{a}}$ diterima dan $\mathrm{H}_{0}$ ditolak yang artinya bahwa secara parsial profitabilitas berpengaruh signifikan terhadap harga saham.

Nilai signifikan DPR, CR, dan NPM secara simultan terhadap Harga Saham adalah sebesar 0,000 0,05 dan nilai $F_{\text {hitung }} 11,604>\mathrm{f}_{\text {tabel }}$ 2,72 sehingga dapat disimpulkan bahwa hipotesis keempat $\left(\mathrm{H}_{4}\right)$ diterima yang berarti terdapat pengaruh DPR, CR, dan NPM secara simultan terhadap Harga Saham pada perusahaan sektor Trade, Services, and Investment di BEI pada periode 2014-2018.

\section{REFRENSI}

Brigham \& Houston. 2012. Dasar-dasar Manajemen Keuangan. Ed 11, Jakarta : Salemba Empat.

Fahmi, Irham. 2013. Pengantar Teori Portofolio dan Analisis Investasi.Bandung : Alfabeta

Ghozali, Imam. 2016. Aplikasi Analisis Multivariate Dengan Program IBM SPSS 23. Jakarta : Penerbit Universitas Diponegoro. 
Kamaluddin \& Rini Indriani. 2012. Manajemen Keuangan. Cetakan Pertama. Jakarta : Bumi Aksara. Mulyawan, Setia. 2015. Manajemen Keuangan. Cetakan Pertama. Bandung : Pustaka Setia.

Subramanyam, K.R \& John J. Wild. 2011. Analisis Laporan Keuangan. Ed.10, Jakarta : Salemba Empat.

Sudana, I Made. 2015. Manajemen Keuangan Perusahaan Teori dan Praktik.Jakarta : Erlangga.

Sugiyono. 2017. Metode Penelitian Kuantitatif, Kualitatif, dam R\&D. Bandung : Penerbit Alfabeta.

Wiyono, Gendro \& Hadri Kusuma.2017. Manajemen Keuangan Lanjutan Berbasis Corporate Value Creation.Ed 1, Yogyakarta : UPP STIM YKPN 